\title{
"KEDUDUKAN TANAH ULAYAT DALAM PERSPEKTIF KONSTITUSI INDONESIA" (Undang-Undang Dasar Negara Republik Indonesia Tahun 1945)
}

\author{
Hairan \\ harbrot@yahoo.co.id \\ Dosen Fakultas Hukum Universitas Mulawarman
}

\begin{abstract}
ABSTRAK
Tanah ulayat adalah bagian dari hak masyarakat adat yang juga sama sebenarnya dengan hak-hak lainnya. Hanya saja dalam konstitusi UUD 1945 belum ada ketegasan mengenai Status Tanah Ulayat sebagai suatu nilai karena tanah ulayat, juga sebagai refleksi dari keberadaan Negara Republik Indonesia. Dalam kemajemukan serta keragaman masyarakat serta haknya adalah adanya nilai yang universal dan dianggap sebagai nilai yang bermakna religius yaitu tanah. Adanya kepentingan yang besar yaitu Negara sangat mendominasi kekuasaan dalam menentukan peruntukan tanah tanpa menjadikan tanah ulayat sebagai salah satu keberadaan dan keragaman hukum dan obyeknya di Indonesia. Sehingga hak menguasai oleh Negara tanpa batasan yang jelas.
\end{abstract}

Kata Kunci: Tanah Ulayat, Konstitusi, UUD 1945

\section{ABSTRACT}

The traditional communal land is part of the rights of indigenous peoples are also the same is true with other rights. Only in the 1945 constitution has been no firmness to the Status of Communal Land as a value for the communal land, as well as a reflection of the existence of the Republic of Indonesia. In the plurality and diversity of society and their rights is a universal value and is considered a significant religious value, namely land. The existence of great importance that the State is dominating power in determining the allocation of land without making the communal land as one of the presence and diversity of law and its object in Indonesia. So that the rights of control by the State without clear boundaries.

Keywords: Communal Land, Constitution, 1945

\section{PENDAHULUAN}

\section{A. Latar Belakang}

Tanah (land) memegang peranan yang sangat penting, karena tanpa adanya tanah

\footnotetext{
${ }^{1}$ Harold J.Laski, memberikan definisi Negara adalah "The state is a society which is integrated by possessing a coerciveauthority legally supreme over any individual or group which is part of the society (Negara adalah suatu masyarakat yang diintegrasikan karena mempunyai
}

maka eksistensi keberadaan Negara $^{1}$ diragukan keberadaan. Bahkan lebih tegas

lagi, bukan diragukan, melainkan adalah unsur terbentuknya Negara.

wewenangyang bersifat memaksa dan yang secara sah lebih berkuasa daripada individu atau kelompok yang merupakan bagian dari masyarakat)." Harold J. Laski, 1947, The State in Theory and Practice, New York, The Viking Press, 1947), page 8-9. 
Tanah menunjukkan wilayah territorial suatu Negara secara horizontal. Lebih luas wilayah teritorial sebenarnya bukan hanya tanah, melainkan seluruh permukaan bumi, baik daratan atau tanah, laut, ruang angkasa, dan yang terkandung di dalamnya.

Undang-Undang Dasar Negara

Republik Indonesia Tahun 1945 (selanjutnya disingkat UUD 1945), tepatnya dalam Pasal 33 ayat (3), menyebutkan:

Bumi dan air dan kekayaan alam yang terkandung di dalamnya dikuasai oleh negara dan dipergunakan untuk sebesar-besar kemakmuran rakyat.

Segala sumber yang ada baik bumi, air, dan kekayaan yang terkandung di dalamnya menjadi hak bangsa Indonesia untuk mengatur peruntukkannya. Pemaknaan bumi disini lebih luas lagi, karena makna "bumi" (earth) meliputi tanah dan air dan ruang angkasa. ${ }^{2}$ Penggunaan kata tanah, tidak dipergunakan dalam rumusan Pasal 33 ayat (3) tersebut. Artinya tanah (land) adalah salah satu bagian dari bumi.

Makna dalam Pasal 33 ayat (3) itu memiliki makna yang mendalam dan sangat universal, memang konstitusi ${ }^{3}$ sebagai hukum dasar Negara dibuat untuk memberikan gambaran yang universal. Sebagai Negara adalah sangat wajar kiranya memiliki kedaulatan untuk menata dan mengatur. Karena kedaulatan itu tidak hanya ditujukan kepada luar saja, yaitu menunjukkan eksistensi keberadaan

2 Lihat dalam Pasal 1 Konvensi Chicago 1944, menyebutkan: The contracting States recognize that every State has complete and exclusive sovereignty over the air-sace above its territory. (Kesepatan bersama Negara-negara mengakui bahwa setiap negara memiliki kedaulatan yang lengkap dan eksklusif melalui udara-disimpan atau di atas wilayahnya). Dipertegas dalam Pasal 2: For the purposes of this Convention the territory of a State shall be deemed to be the land areas and territorial waters adjacent there to under the sovereignty, suzerainty, protection or mandate of such State (Untuk tujuan Konvensi ini wilayah Negara dianggap menjadi lahan dan perairan teritorial yang berdampingan kepada Negara-negara lain atau internasional.

Negara memiliki hak untuk mengatur wilayahnya, salah satunya adalah tanah. Pengaturan Negara dalam hal ini Negara Republik Indonesia melaksanakan perintah Konstitusi yang ketentuan Pasal 33 ayat (3) UD 1945 tersebut. Bahasa yang dikeluarkan dalam Pasal 33 ayat (3) UUD 1945 untuk menunjukkan keberadaan Negara, dan Negara memiliki kekuasaan tertinggi sangat universal dan memiliki makna yang mendalam. Apalagi Indonesia yang dikenal sebagai Negara kepulauan (Archipalago). Banyak pulau besar dan pulau kecil yang berjumlah sekitar lebih dari 17 ribu pulau. Dipulau-pulau inilah kita bertempat melaksanakan aktivitas hukum.

Pulau yang sering kita sebut daratan, dan semua aktivitas manusia berada di darat. Daratan inilah yang kita sebut juga dengan tanah. Tanah memiliki makna yang sangat penting baik dalam sejarah (history), peradaban manusia dari masa ke masa. Tanah juga memiliki nilai ekonomi, nilai sosial, dan terpenting juga tidak bisa dikesampingkan adalah nilai Magic Religoius. Negara mengatur secara sentralistik peruntukannya yang secara filsafat, pengaturannya hanya untuk sebesar-benar kemakmuran rakyat. Tugas Negara, adalah merencanakan ruang, menata, dan melaksanakan peruntukan dan melegalisasi hak atas tanah yang diberikan negara. Ketentuan Pasal 33 ayat (3) UUD

dengannya di bawah kedaulatan, kekuasaan, perlindungan atau mandat dari Negara tersebut).

3 a constitution is more than a social contract ....... it is rather an expression of the general will of a nation. It is a reflection its history, fears, concerns, aspirations and indeed, the soul of the nation" (Kalimat ini berasal dari Cheryl Saunders Guru Besar Hukum Tata Negara pada Universitas Melbourne Asutralia, dikutip dalam Bagir Manan dan Susi Dwi Harijanti, 2015, Memaknai Konstitusi, Makna dan Aktualisasi, Jakarta, Raja Grafindo Persada, hlm ix. 
1945, sebagai nilai dasar yang wajib ditindaklanjuti dengan norma berupa pembentukan Undang-undang Nomor 5 Tahun 1960 tentang Peraturan Dasar Pokok-pokok Agraria, (Selanjutnya disingkat UUPA). Sampai saat ini UUPA menjadi dasar untuk mengatur peruntukan tanah. Ketentuan pasal 33 ayat 3 UUD 1945 dijewantahkan dalam Pasal 2 ayat (1) yang menyatakan bahwa:

"Atas dasar ketentuan dalam Pasal 33 ayat 3 Undang-Undang Dasar dan halhal sebagai yang di maksud dalam Pasal 1, bumi, air, dan ruang angkasa, termasuk kekayaan alam yang terkandung didalamnya itu pada tingkatan tertinggi kekayaan alam yang terkandung di dalamnya itu pada tingkatan tertinggi dikuasai oleh Negara, sebagai organisasi kekuasaan seluruh rakyat."

Dalam penjelasan umum UUPA angka 2 lebih lanjut dijelaskan bahwa:

“ .......tidak perlu dan tidak pula pada tempatnya, bahwa Bangsa Indonesia ataupun Negara bertindak sebagai pemilik tanah. Adalah lebih tepat jika Negara , sebagai organisasi kekuasaan dari seluruh rakyat (bangsa) bertindak selaku Badan Penguasa “.

Negara dalam kedudukannya sebagai organisasi kekuasaan seluruh rakyat, berdasarkan ketentuan Pasal 2 ayat 2 UUPA diberi wewenang untuk:

a. mengatur dan menyelenggarakan peruntukan, penggunaan, persediaan dan pemeliharaan bumi, air dan ruang angkasa;

b. menentukan dan mengatur hubunganhubungan hukum antara orang-orang dengan bumi, air dan ruang angkasa;

c. menentukan dan mengatur hubunganhubungan hukum antara orang-orang,

4 Lihat Muhammad Bakri. Hak bangsa merupakan hak penguasaan atas tanah yang tertinggi dalam hukum tanah nasional. Hakhak penguasaan atas tanah yang lain, secara langsung maupun tidak langsung bersumber padanya. Hak bangsa mengandung dua unsur, yaitu kepunyaan dan unsure tugas kewenangan untuk mengatur dan memimpin penguasaan dan penggunaan tanah yang dipunyainya. Hak bangsa atas tanah bersama dan perbuatan hukum yang mengenai bumi, air dan ruang angkasa.

Atas dasar tersebut Negara mengatur berbagai hal terkaait dengan tanah, karena hak tertinggi adalah hak bangsa, baru kemudian hak menguasai tanah oleh Negara. Menurut Bakrie, Seluruh Wilayah Indonesia adalah kesatuan tanah air dari seluruh rakyat Indonesia yang bersatu sebagai Bangsa Indonesia",.

Nilai dasar yang dimuat dalam Pasal 33 ayat (3) UUD 1945 itu, menyangkut obyek dimana kedudukan Negara sebagai subyek hukum berupa badan hukum (rechts persoon), karena Negara sebagai organisasi besar yang menyelenggarakan sistem kehidupan berbangsa, bernegara, dan bermasyarakat. Kehidupan berbangsa, bernegara, dan bermasyarakat itu ditujukan kepada siapa? Ditujukan kepada segenap rakyat Indonesia, yang pada kenyataannya adalah majemuk dalam berbagai hal, mulai keragaman bahasa, keragaman berpakaian, keragaman budaya, sampai keragaman dalam hukum adat dan keragaman dalam memperlakukan tanah sebagai haknya.

Daya tangkap yang tersurat dalam Pasal 33 ayat (3) UUD 1945 itu tidak ditangkap sepenuhnya dalam UUPA. Buktinya pernyataan yang secara jujur menyatakan pengaturan tanah oleh Negara tidak lepas dari resepsi dari hukum barat dan hukum adat ke dalam UUPA. Sayangnya UUPA tidak melakukan konkretisasi terhadap pengakuan dan pengaturan hak atas tanah. Sedangkan dalam ketentuan Pasal 2 ayat (4) UUPA, menyebutkan:

Hak menguasai dari Negara tersebut diatas pelaksanaannya dapat dikuasakan kepada daerah-daerah Swatantra dan

tersebut bukan hak pemilikan dalam pengertian yuridis. Maka dalam rangka Hak Bangsa ada hak milik perorangan atas tanah. Tugas kewenangan untuk mengatur penguasaan dan memimpin penggunaan tanah bersama tersebut pelaksanaannya dilimpahkan kepada Negara. Muhammad Bakri, Hak Menguasai Tanah Oleh Negara (Paradigma Baru Untuk Reforma Agraria), Citra Media Hukum: Yogyakarta: 2007, hlm.42. 
masyarakat-masyarakat hukum adat, sekedar diperlukan dan tidak bertentangan dengan kepentingan nasional, menurut ketentuan-ketentuan Peraturan Pemerintah.

Setelah reformasi dengan tuntutan yang salah satunya adalah tonomi daerah, merambah pula perlakuan bagi masyarakat adat. Sehingga hasil amandemen ke 2 dalam Pasal 18B ayat (2), menyebutkan:

Negara mengakui dan menghormati kesatuan-kesatuan masyarakat hukum adat beserta hak-hak tradisionalnya sepanjang masih hidup dan sesuai dengan perkembangan masyarakat dan prinsip Negara Kesatuan Republik Indonesia, yang diatur dalam undang-undang. Ketentuan Pasal 18B ayat (2) ini, Negara menyatakan pengakuannya terhadap subyek hukum Adat beserta hak-hak tradisionalnya. Hak-hak tradisional ini dikalangan kita sering memperdebatkan, apakah juga termasuk tanah adat. UUPA yang telah ada sejak tahun 1960, nuansa politik hukum yang dibangun sistem hukum agraria, dalam arti sempit hukum tanah didasarkan pada hukum barat dan hukum adat, tetapi UUPA dalam Pasal 3, menyebutkan:

Dengan mengingat ketentuanketentuan dalam pasal 1 dan 2 pelaksanaan hak ulayat dan hak-hak yang serupa itu dari masyarakat-masyarakat hukum adat, sepanjang menurut kenyataannya. masih ada, harus sedemikian rupa sehingga sesuai dengan kepentingan nasional dan Negara, yang berdasarkan atas persatuan bangsa serta tidak boleh bertentangan dengan Undang-undang dan peraturanperaturan lain yang lebih tinggi.

Adanya Pasal 18B ayat (2) UUD 1945 ini, mengenai pengertian masyarakat hukum adat, menurut Roestandi Ardiwilaga bahwa:

Masyarakat hukum adat (adatrecht gemeenschap) adalah tidak lain dari pada kesatuan manusia yang teratur, menetap di suatu daerah tertentu, mempunyai

5 Roestandi Ardiwilaga, 1962, Hukum Agraria Indonesia, Penerbit Masa Bakti, Jakarta, hlm 23 penguasa-penguasa dan mempunyai kekayaan yang berwujud ataupun tidak berwujud, di mana para anggota kesatuan masing-masing mengalami kehidupan yang wajar menurut kodrat alam dan tidak seorangpun di antara para anggota itu mempunyai pikiran atau kecenderungan untuk membubarkan ikatan yang telah bertumbuh itu atau meninggalkan dalam arti melepaskan diri dari ikatan itu untuk selama-lamanya. ${ }^{5}$

Sekarang ini dengan masa demokrasi di Indonesia sebagian masyarakat di daerah menuntut hak-hak kedaerahan, salah satunya adalah pengakuan hak-hak masyarakat adat yaitu tanah adat. Hanya saja Negara belum jelas memasukkan tanah adat itu sebagai hak jelas dan pasti dan seperti apa implementasinya. Adanya kekhawatiran terhadap status hak tanah ulayat diberikan bisa menjadi masalah bagi Negara, karena adanya kepentingan-kepentingan yang lebih besar lagi.

Banyak permasalahan tanah ini terjadi di beberapa daerah dilator belakangi karena kepentingan tadi, dominasi Negara dalam menguasai tanah oleh Negara, menyebabkan Negara terjebak pada konflik pertanahan baik secara konflik bersifat vertikal maupun konflik yang bersifat horizontal. Kejelasan yang masih dianggap kabur dalam konstitusi kita, yaitu UUD 1945 mengenai bentuk pengakuan hak-hak masyarakat adat, dalam hal tanah adat. UUPA tidak memasukkan tanah adat sebagai suatu status hak yang dimiliki oleh komunitas masyarakat adat, tetapi lebih menekankan pada penguasaan tanah oleh Negara. Sedangkan kepemilikan dilakukan secara individual. ${ }^{6}$

Bila di bidang kehutanan Undangundang Nomor 41 Tahun 1999 tentang Kehutanan, tepatnya dalam Pasal 5 yang mengatur tentang status hutan. Dimana hutan menurut statusnya dikelompokkan menjadi 2, yaitu hutan dengan status hutan Negara, dan hutan dengan status hutan hak.

6 Lihat ketentuan Pasal 16 ayat (1) dan ayat (2) UUPA, yang mengatur macam-macam hak atas tanah. 
Hutan adat masuk dalam kategori hutan Negara. Sehingga Mahkamah Konstitusi, pada 16 Mei 2013, Mahkamah Konstitusi mengeluarkan Putusan No.35/2012 yang monumental dengan menegaskan konstitusionalitas hutan adat. Mahkamah Konstitusi (MK) memutuskan bahwa kata "negara" dalam Pasal 1 angka 6 UU No. 41 tahun 1999 tentang Kehutanan bertentangan dengan Konstitusi. Pasal tersebut awalnya berbunyi: "hutan adat adalah hutan negara yang berada dalam wilayah masyarakat hukum adat"diubah oleh Putusan MK menjadi, "hutan adat adalah hutan yang berada dalam wilayah masyarakat hukum adat."

Hal kehutanan telah jelas, walaupun diakui implementasinya dilapangan masih tertatih-tatih, misalnya penataan ruang yang setengah hati dari Daerah untuk memasukkannya dalam Rencana Tata Ruang Wilayah (RTRW) baik Provinsi maupun Kab/Kota di Indonesia. Padahal memasukkan dalam tata ruang wilayah Provinsi dan Kabupaten/Kota menjadi kewajiban sebagai bentuk tanggungjawab Negara dalam konstitusi tadi mengakui keberadaannya, meskipun dengan syarat sepanjang masih ada keberadaannya. Untuk status tanah sampai saat sekarang ini belum ada bentuk regulasi yang menjadi norma konkret untuk mengatur status keberadaan tanah ulayat atau yang kita sebut dengan Hak Ulayat.

\section{B. Permasalahan}

1. Apakah status hak ulayat dalam Konstitusi Indonesia, yaitu UndangUndang Dasar Negara Republik Indonesia Tahun 1945?

2. Apakah Hak Ulayat itu telah memiliki kepastian hukum?

\section{Tujuan Penulisan}

Tujuan yang ingin dicapai dari penulisan ini, sebagai berikut:

1. Menempatkan tanah Adat dalam kedudukan sebagai tanah hak, bukan

7 Jimly Asshiddiqie, 2000, Pembentukan dan Pembuatan Hukum, Jakarta, Universitas Indonesia, hlm 54 sebagai tanah Negara. Artinya mendudukan secara hukum dalam kesetaraan yang sejajar dengan hak lainnya.

2. Terbangunnya sistem hukum yang bisa memberikan jaminan kepastian hukum bagi keberadaan tanah adat yang sepanjang keberdaannya masih diakui.

\section{PEMBAHASAN}

\section{Status tanah Ulayat dalam konstitusi Indonesia, yaitu Undang-Undang Dasar Negara Republik Indonesia Tahun 1945.}

\section{a. Memaknai Status Tanah Ulayat dalam Konstitusi Indonesia}

Begitu banyak bahasan mengenai hukum adat dan tanah ulayat, tetapi kita terlupa mengenai status tanah adat itu seperti apa Negara mengakomodirnya mulai dari konstitusi dan sistem hukum yang ada. Jangan lupa bahwa secara tegas dan lugas, bangsa kita menyatakan Negara ini adalah Negara yang berdasarkan hukum, sebagaimana dalam Pasal 1 ayat (3) UUD 1945, amandemen ketiga, menyatakan:

Negara Indonesia adalah negara hukum. Jelas hukum yang diinginkan, bukan menggunakan perundangundangan. Makna hukum itu luas sekali, tergantung kita memaknainya dari sudut pandang yang mana. Bila dipandang hukum itu sebagai suatu aturan normatif, maka menurut Jimly Asshiddiqie, menyatakan: Hukum adalah keseluruhan aturan normatif yang mengatur dan menjadi pedoman perilaku dalam kehidupan bermasyarakat dan bernegara dengan di dukung oleh sistem sanksi tertentu terhadap setiap penyimpangan terhadapnya. ${ }^{7}$

Hukum dipandang sebagai pedoman perilaku dalam kehidupan bermasyarakat dan bernegara, jelas hukumlah yang 
membatasi perilaku, karena manusia cenderung menyimpang dari apa yang seharusnya tidak dilakukan. Dalam hukum ada sumber-sumber formal, yang salah satunya adalah kebiasaan (costum). Kebiasaan (costum) dilakukan berulang ulang juga menjadi hukum, termasuk dalam hal ini adalah hukum adat. Karena dia lahir dari adanya kebersamaan dan kekeluargaan dikalangan masyarakat Indonesia yang beraneka ragam. Kebersamaa dan kekeluargaan adalah sebuah konsep budaya yang hidup di masyarakat Indonesia. Hal ini berbeda dengan kultur barat yang cederung hidup secara individualistis. Bangsa Indonesia memiliki nilai-nilai luhur budaya yang sangat menjunjung tinggi kebersamaan dan gotong royong. ${ }^{8}$

Tanah adat sebagai obyek, dipandang sangat penting bagi masyarakat adat. Masing-masing komunitas masyarakat adat secara universal memiliki kesamaan dalam memandang tanah. Tanah dianggap tempat yang sakral dan perlu dijaga dan dipelihara. Tanah dipandang juga sebagai nilai dari suatu keberadaan dan eksistensi hukum adat itu sendiri. Untuk menuju status tanah adat dalam kedudukan sebagai tanah hak, maka perting terlebih dulu dibedakan tanah adat tersebut. Tanah adat itu dapat dibedakan menjadi 2 (dua), yaitu tanah adat perorangan dan tanah adat komunal, yang disebut Tanah Ulayat. Sedangkan hak ulayat itu menyangkut perbuatan apa saja yang dapat dilakukan oleh masyarakat hukum adat. Menurut Boedi Harsono menyatakan bahwa: "Hak ulayat merupakan serangkaian dari pada wewenang dan kewajiban-kewajiban suatu masyarakat hukum adat termasuk lingkungan wilayahnya. Hak ulayat berlaku terhadap semua tanah wilayah itu, baik yang sudah dihaki seseorang maupun

8 Yanis Maladi, Eksistensi Hukum Adat Dalam Konstitusi Negara Pasca amandemen, Jurnal Mimbar Hukum, Vol 22, Nomor 3, Oktober 2010 hlm 453

9 Boedi Harsono, Hukum Agraria Indonesia, Sejarah Pembentukan Undang-undang Pokok yang tidak atau belum dihaki." ${ }^{9}$ Pendapat lain yang menurut Penulis mendekati dengan pengelompokkan tanah ulayat dari pengertian hak ulayat, yaitu seperti pendapat dari Mertokusumo, beliau mengatakan bahwa hak ulayat adalah :

"Hak atas tanah yang menjadi milik bersama masyarakat, yang merupakan hak tertinggi kedudukannya. Hak ulayat mengandung dua unsur kepunyaan artinya semua anggota masyarakat mempunyai hak untuk menggunakan dan unsur kewenangan yaitu untuk mengatur, merencanakan dan memimpin penggunaannya. Kemudian karena semua anggota masyarakat tidak mungkin melaksanakan pengurusan hak ulayat, maka tugas tersebut dilimpahkan kepada kepala adat. Jadi pelimpahan itu, kepala adat berhak memberikan hak-hak atas tanah kepada perseorangan seperti hak milik, hak yayasan, hak pakai dan lainlain. $^{10}$

Pelimpahan inilah yang menjadi tanah adat perorangan yang kemudian bila dia mendaftarkan kepada Negara secara formal, maka hapuslah sudah tanah adat tersebut, karena dengan sukarela dia tunduk kepada hukum Negara untuk melegalisasi secara formal dalam bentuk hak milik, hak yayasan, hak pakai dan lainnya. Lalu dengan demikian bentuk pengakuan tanah ulayat dalam hukum formal oleh Negara juga bisa dipandang hapusnya tanah ulayat? Disinilah Negara berperan untuk memberikan bentuk jaminan konstitusi atas tanah ulayat itu, dengan tanpa meninggalkan hak menguasai oleh Negara. Hak Bangsa adalah segala-galanya dan tertinggi dari semua hak. Hak Negara merupakan bentuk bentuk pengaturan atas hak-hak atas tanah, termasuk peruntukannya.

Atas pendapat ini, Penulis merasakan adanya kokosongan konstitusi

Agraria, Isi dan Pelaksanaannya, Djambatan, Jakarta, 1999, hal. 162-164

10 Mertokusumo, Pendaftaran Hak Atas Tanah Menurut UUPA, Karunika, Jakarta, 1988, hal. 419 
dalam hukum terhadap bentuk pengakuan oleh Negara bagi tanah ulayat. Memang benar dan Penulis sepakat secara mendasar Pasal 33 ayat (3) UUD 1945 itulah yang menaungi, Lalu bagaimana dengan bentuk pengakuan Negara terhadap Pasal 18B ayat (2) UUD 1945. Dimana kita mendudukan Tanah Ulayat, sekali lagi tanah ulayat, bukan pada pengertian tanah adat. Tanah adat akhirnya ditafsirkan sebagai tanah perorangan. Jadi disini dibatasi tanah ulayat, sebagai bentuk penguasaan tanah secara bersama-sama (communal). Hak yang dimiliki dan pemanfaatan bersama pula.

Penulis sependapat dengan pengertian yang disampaikan Mertokusumo di atas. Karena pada faktanya sangat mendekati dengan kenyataan yang sesungguhnya, riil terjadi dimasyarakat Indonesia secara universal. Hanya dalam tatanan masing-masing masyarakat adat berbeda memberlakukannya. Hampir sebagian besar konflik tanah melibatkan masyarakat adat yang menuntut haknya atas tanah karena Negara dengan hak menguasai oleh Negara mengabaikan keberadaan mereka dalam menjaga dan memelihara tanah ulayatnya. Namun demikian, Penulis juga secara obyektif mengatakan terjadi kekaburan tanah ulayat di beberapa daerah, salah satunya adalah Kalimantan (Borneo). Sejak Van Vollen Hoven melakukan penelitian (research). Salah satu kelemahan Tanah Ulayat batas wilayahnya yang didasarkan pada alam. Masa sekarang ini dimana kita selalu membutuhkan adanya bentuk kepastian hukum, yang salah satunya menyangkut status tanah adalah batas-batas yang jelas, berupa data fisik. Tanpa adanya kepastian hukum itu, maka dianggap kaburnya status hak tersebut.

11 I Nyoman Nurjaya and Rachmad Syafaat, Acces to Ecological Justice For The Marginalized People of Indonesia: Is it a Genuine or Pseudo Recognition and Respect, Jurnal Indonesia Law Review, Vol 6, 1, 2016, page106
Negara dalam hal ini Indonesia dengan konstitusinya yaitu UUD 1945 mengakomodir nilai-nilai universal dalam keragaman budaya, hukum, sosial, dan ekonomi. Kegaraman ini menurut I Nyoman Nurjaya, mengatakan: It is a fact that Indonesia is a multicultural country interms of ethnicity, religion, language, and social stratifications, including the existence of multi-system of law namely State law on the one hand and religious law, customary law or adat law on the other hand. ${ }^{11}$

Fakta ini tidak bisa dikesampingkan oleh Negara dalam menuangkan nilai-nilai dasar dalam konstitusi. Lalu apa yang jadi persoalannya. Persoalannya adalah Negara merupakan organisasi terbesar yang wajib mampu mengayomi seluruh tumpah darah tanah air Indonesia, sebagai hak bangsa. Namun demikian pula Negara wajib mampu memberikan jaminan kepastian hukum status suatu obyek yang berada dalam penguasaan dan pengaturan Negara. Dalam hal ini Penulis berpendapat, hak menguasai oleh Negara atas tanah juga ada pembatasan, karena adanya Pasal $18 \mathrm{~B}$ ayat (2) UUD 1945 itu dapat dimaknai sebagai bentuk pembatasan, karena konstitusi telah memberikan pengakuan, meskipun disertai syarat, "sepanjang". Pendapat penulis ini diperkuat oleh Bakrie, berpendapat: Hubungan hukum antara Negara dengan tanah melahirkan hak menguasai tanah oleh Negara (HMN), hubungan hukum antara orang dengan tanah melahirkan hak perorangan atas tanah. Peraturan perundang-undangan di bidang agraria memberi kekuasaan yang besar kepada Negara untuk menguasai semua tanah yang ada di wilayah Indonesia, sehingga berpotensi melanggar hak ulayat dan hak perorangan atas tanah. ${ }^{12}$

12 Bakrie, Abtraksi Disertasi Pembatasan Hak Menguasai Tanah Oleh Negara Dalam Hubungannya Dengan Hak Ulayat dan Hak Perorangan Atas Tanah., Fakultas Hukum, Universitas Airlangga, http://repository.unair.ac.id/, 02 Nopember 2016. 


\section{Kedudukan Tanah Ulayat terhadap Hak Menguasai oleh Negara}

Bicara soal kedudukan Tanah Adat, maka harus dipertegas mengenai kedudukan tanah adat seperti apa yang dimaksud terhadap Hak menguasai tanah oleh Negara. Menurut Abrar Saleng dalam Andi Bustamin Daeng Kunu, menjelaskan: ${ }^{13}$ HPN sebagai konsep sampai saat ini belum mempunyai konsep serta makna yang jelas dan tegas yang dapat diterima oleh semua pihak dalam hubungannya dengan pengelolaan dan pemanfaatan sumber daya alam nasional, sehingga mengundang banyak penafsiran yang berimplikasi kepada implementasinya. Perbedaan implementasi ini baik dalam peraturan perundangundangan maupun dalam pelaksanaannya oleh departemen/instansi pemerintah terkait. Akibatnya sering terjadi benturan atau komplik kepentingan dan kewenangan dalam pengelolaan dan pemanfaatan sumber daya alam nasional.

Pendapat di atas menjadi salah satu sandaran kita dan membuktikan bahwa sebenarnya Hak menguasai oleh Negara itu masih menjadi ketidak jelasan. Tidak ada pembatasan yang jelas sampai dimana Negara itu menguasai. Bila penguasaan secara mutlak itu bisa diterima, tetapi sebaiknya ada batasan yang jelas. Tanah merupakan bagian dari Sumber Daya Alam (Natural resources) yang haknya dalam pandangan sejarahnya, jauh sudah ada penguasaan haknya oleh masyarakat adat sebelum negara ini terbentuk pada tanggal 17 Agustus 1945.

UUD 1945 sebagai konstitusi telah menambahkan dalam amandemen kedua dalam Pasal 18B ayat (2), bentuk pengakuan hak-hak masyarakat adat ini meliputi apa saja menjadi sangat universal. Tafsiran-tafsiran akan muncul ketika Pasal ini memerintahkan dibentuk undang-

13 Andi Bustamin Daeng Kunu, Kedudukan Hak Menguasai Negara Atas Tanah, Fiat Justitia Jurnal Ilmu Hukum Volume 6 No. 1 Januari-April 2012, ISSN 1978-5186, tanpa halaman, http://download.portalgaruda.org, tanggal 2 Nopember 2016 undang. Bila itu "hak" ditujukan pada subyek hukum, maka kenapa tidak menjadi bagian dari Hak Asasi Manusia (HAM), sebagaimana HAM tersebut disebutkan dalam Pasal 28A sampai dengan Pasal 28J.

Baiklah, kembali lagi pada hak menguasai oleh Negara, apa yang tertulis dalam konstitusi UUD 1945, mengenai tanah ulayat begitu kuatnya kepentingan dengan mengatasnamakan Negara. Sehingga terkesan nuansa filsafat itu meyakinkan bahwa Pasal 18B ayat (2) Negara bersungguh-sungguh mengakui dan menghormati, tetapi tidak ada penegasan Negara terhadap tanah ulayah itu sebagai suatu hak yang pasti.

Fakta sekarang ini, di banyak daerah, terjadi konflik tanah yang tidak jarang melibatkan Negara sebagai melalui Pemerintah dan Pemerintah Daerah sebagai pelaksanaan Negara. Konflik Mesuji di Lampung, konflik perusahaan pemegang usaha perkebunan dengan warga setempat. Di Kalimantan banyak konflik usaha kehutanan, pertambangan, dan perkebunan oleh Pemegang izin usaha itu dengan masyarakat adat. Konflik itu kemudian digunakan cara-cara lama yang digunakan kolonial Belanda dengan politik "deveda et ampera", yaitu adu domba sesama kelompok masyarakat dengan kelompok masyarakat lain dengan mengatasnamakan masyarakat adat. Ini adalah fakta hukum yang secara empiris tidak bisa dibantah, bahwa Negara telah menciptakan konflik pertanahan. Memang diakui banyak latar belakang terjadinya konflik itu, dari persfektif antropologi hukum, menurut I Nyoman Nurjaya, mengatakan: ${ }^{14}$ Fenomena konflik dalam masyarakat muncul paling tidak karena adanya konflik Nilai (conflik of value), konflik norma (conflict of norm), dan/atau konflik kepentingan (conflict of interest) dalam kehidupan bersama. Selain itu,

14 I Nyoman Nurjaya, 2004, 2006, dalam Jurnal berjudul: Pembangunan Hukum Negara Dalam Masyarakat Multikultur: Perspektif Hukum Progresif, Jurnal Hukum Progresif, Vol 3 No.2, Oktober 2007, hlm 14. 
secara empiris konflik-konflik yang terjadi juga dapat bersumber dari persoalan dominasi dan diskriminasi dalam peraturan hukum Negara (State law) dan perlakuan pemerintah (government treatment) terhadap masyarakat di daerah, yang mengabaikan, menggusur, dan bahkan mematisurikan nilai-nilai, prinsip-prinsip dan norma-norma hukum rakyat (customary law/fork law/indigenous law/adat law), termasuk sistem religi dan tradisi komunitas-komunitas masyarakat adat (adat communities) atas nama pembangunan nasional (in the name of development), khususnya pembangunan di bidang hukum yang dikemas sebagai pembangunan hukum nasional. Hak menguasai Negara dipandang tidak ada kompromi terhadap keberadaan hak-hak masyarakat adat, khususnya adalah tanah ulayat. Pengambilalihan tanah oleh investor dengan izin yang diperoleh dari Negara menjadi senjata utama, bahwa izin itu adalah segalanya. Masyarakat adat yang sejak lama mengelola tanah ulayatnya secara bersama-sama menjadi hilang. Fakta-fakta ini menjadi renungan kita bersama bahwa Negara ini dibangun karena adanya unsur-unsur yang saling berhubungan erat. Salah satu unsur tidak terpenuhi, maka tidak mungkin Negara Republik Indonesia (NKRI) ini ada. Tanah merupakan salah satu unsur, masyarakat pun juga unsur terbentuknya Negara, maka tidak salah UUD 1945 dalam Pasal 1 ayat (2) menyatakan: "Kedaulatan berada di tangan rakyat dan dilaksanakan menurut Undang-Undang Dasar" Hak menguasai oleh Negara, adalah bentuk kekuasaan yang dominasi sekali untuk kepentingan tertentu, sehingga perlu diperdebatkan kepentingan yang mana. Biasanya dengan atas nama Negara, ini adalah kepentingan yang lebih besar. Makna ini dimakanai sebagai bentuk legalisasi untuk menghilangkan kepentingan yang dianggap kecil. Jelas bahwa kekuasaan Negara terhadap hak menguasai Negara atas tanah pun dibatasi dipertegas dalam

15 Bagir Manan dan Susi Dwi Harijanti, 2015, Op Cit, hlm 146. konstitusi, karena menurut Bagir Manan dan Susi Dwi Harijanti, mengatakan: Mengapa harus ada pembatasan kekuasaan? Seperti sering kita dengar atau baca yang mengatakan "power tends to corrupt, absolute power corrupts absolutely (Action)". Tanpa pembatasan, kekuasaan akan dijalankan secara sewenang-wenang (arbitrary, willekeur). ${ }^{15}$ Itulah kenapa kekuasaan Negara pun dibatasi. Walaupun nilai-nilai yang tertuang dalam Konstitusi yaitu UUD 1945 tidak semua bisa terpenuhi, tetapi paling tidak adanya kejelasan dan kepastian bentuk pengakuan dan penghormatan itu oleh Negara. Hal ini menjadi perdebatan, apakah Konstitusi itu mampu memuat semua nilai-nilai universal. maka lebih lanjut Bagir Manan dan Susi Dwi Harijanti, mengatakan: Apakah kalau sudah ada konstitusi, akan ada pembatasan kekuasaan? Belum tentu. Mengapa? Realitas pembatasan kekuasaan tidak ditentukan konstitusi atau kaidah hukum, melainkan oleh tingkah laku penyelenggara Negara, dan tingkah laku penyelenggara Negara ditentukan pula oleh berbagai hal seperti idiologi, tatanan politik, kepentingan kekuasaan dan lainlain. ${ }^{16}$

Dari semua itu yang terpenting adalah menurut Penulis, Konstitusi UUD 1945 terhadap Pasal 18B ayat (2), belum ada kejelasan yang pasti bagaimana Negara mengakomodir pengakuan status tanah ulayat bukan lagi sebagai bagian dari tanah Negara, melainkan menjadi tanah hak. Sayangnya, UUPA dalam batang tubuh Pasal 1 sampai Pasal 15 memuat yang menjadikan hak ulayat dalam hal ini tanah ulayat sebagai bagian keragaman status hukum tanah dari dualismenya hukum tanah yaitu hukum barat dan hukum adat. Demikian pula dalam penjelasan, secara sadar pembentuk UUPA ini menjadikan Hukum adat sebagai salah satu dasar pembentukan UUPA tersebut.Hanya saja dari Pasal 16 dan seterusnya mengenai macam-macam hak 16 Bagir Manan dan Susi Dwi Harijanti, 2015,
Op Cit 
tidak ada satupun pasal yang memberikan ruang kepastian dengan menyebutkan Tanah Ulayat sebagai salah satu macammacam hak. Secara berimbang juga Penulis memberikan kesimbangan hukum terhadap kepastian hukum Tanah Ulayat yang dibangun pun adalah terbatas. Bila tidak, maka Negara juga tidak berdaya dalam menghadapi persoalan yang lebih besar, misalnya menyangkut kedaulatan Negara. Pada sekarang ini dimana Negara dihadapkan untuk dapat menerapkan keseimbangan, yaitu teori kekuatan atau teori pengakuan. Kedua teori ini menurut Soedikno Mertokusumo, mengatakan:

1. Teori kekuatan (machtstheorie) hukum mempunyai kekuatan berlaku secara sosiologis apabila dipaksakan berlakunya oleh penguasa, terlepas dari diterima ataupun tidak oleh warga masyarakat.

2. Teori (anerkennungstheorie) hukum mempunyai kekuatan berlaku sosiologis apabila diterima dan diakui oleh warga masyarakat. ${ }^{17}$

Tentunya penerapan teori ini bukanlah pilihan (choice), melainkan adalah membangunnya dengan kesimbangan dari keduanya. Konstitusi kita UUD 1945 Pasal 18B ayat (2) masih sebatas pengakuan, tidak menjadikan Tanah ulayat sebagai suatu kekuatan hukum, kekuatan dalam membangun ekonomi dan sosial kedepan.

\section{Kejelasan Tanah Ulayat dapat pengakuan agar terjamin kepastian hukum}

a. Reforma Hukum Tanah dan Perlindungan Tanah Ulayat dalam Sistem Hukum Indonesia

Sekarang ini pembangunan hukum di Indonesia terkait dengan reformasi hukum pertanahan masih jalan ditempat. Upaya yang yang dihadirkan dalam membangun hukum pertanahan, terutama bentuk jaminan kepastian hukum belum ada, hanya sebatas pada pengakuan dan upaya penyelesaian konflik tanah.
Sebaran Undang-undang memang mengatur sebagian terkait dengan pengakuan hak-hak masyarakat adat, khususnya tanah ulayat. Seperti dalam Undang-undang Nomor 4 Tahun 2009 tentang Mineral dan Bara, tepatnya dalam ketentuan Pasal 66 sampai Pasal 73 mengatur tentang Izin Tambang Rakyat, tambang rakyat dimaknai adalah tambah tradisional diatas tanah ulayat dilakukan bersama-sama, juga diatur dengan izin Negara. Sekarang Izin Tambang Rakyat (IPR) ini pengaturannya di atur Kabupaten/Kota, maka dengan adanya berlakuknya Undang-undang Nomor 23 Tahun 2014 tentang Pemerintahan Daerah menjadi kewenangan Pemerintah Provinsi. Sebaran lain juga masih sebatas pengakuan dalam upaya penyelesaian masalah tanah ulayat, yaitu dalam Undang-undang Nomor 39 Tahun 2014 tentang Perkebunan, mengatur upaya penyelesaian terlebih dulu mengenai penggunaan tanah dengan masyarakat adat oleh investor sebagaimana diatur dalam Pasal 12 ayat (1) dan ayat (2), menyebutkan:

“Ayat (1) Dalam hal tanah yang ditujukan untuk Usaha Perkebunan merupakan Tanah Hak Ulayat Masyarakat Hukum Adat, Pelaku Usaha Perkebunan harus melakukan musyawarah dengan Masayarakat Hukum Adat pemegang Hak Ulayat untuk memperoleh persetujuan mengenai penyerahan Tanah dan imbalannya." "Ayat (2) Musyawarah dengan Masyarakat Hukum Adat pemegang Hak Ulayat sebagaimana dimaksud pada ayat (1) dilaksanakan sesuai dengan ketentuan peraturan perundang-undangan".

Ketentuan Pasal ini bisa diterima, tetapi menjadi persoalannya adalah bagaimana apabila tidak ada jalan musyawarah. Jelas sebagaimana di tertuang pada ayat (2) itu, dilaksanakan sesuai ketentuan peraturan perundangundangan.

Tafsirannya sangatlah melemahkan bagi masyarakat adat, tidak ada daya tawar

17 Soedikno Mertokusumo 2002, Mengenal Hukum, Liberty, Yogyakarta, hlm 87 
untuk menolak. Sebab peraturna yang dimaksud adalah Alternatif Dispute Resolution (ADR), yaitu sebagaimana disatur dalam Undang-Undang Republik Indonesia Nomor 30 Tahun 1999 Tentang Arbitrase dan Alternatif Penyelesaian Sengketa. Akhirnya bila tidak terselesaikan, maka dilaksanakan upaya hukum litigasi atau melalui jalur pengadilan.

Mengingat bahwa masyarakat hukum adat itu dianggap sebagai subyek hukum yang berbentuk badan, maka untuk bisa melakukan upaya penyelesaian dalam musyawarah masyarakat adat terlebih dulu telah ditetapkan terlebih dulu secara hukum. Hal ini sebagaimana diatur dalam Pasal 13, Undang-undang Nomor 39 Tahun 2014 tentang Perkebunan, yaitu: Masyarakat Hukum Adat sebagaimana Pasal 12 ayat (1) ditetapkan sesuai peraturan perundang-undangan.

Ketentuan ini kemudian mengkerdilkan kembali masyarakat adat dalam mempertahankan dan atau memperoleh haknya sebagai masyarakat adat atas tanah ulayatnya. Bagaimana bila belum ditetapkan, tentunya Pihak pemegang izin usaha dengan paham positivistis ini berbpegang teguh pada ketentuan Undang-undang ini. Penyelesaian melalui jalur pengadilan dianggap tidak efektif, meskipun memberikan kepastian hukum, tetapi persoalannya, tingkat kepercayaan (trust) kepada pengadilan sekarang ini masih rendah. Keberpihakan pengadilan tidak jarang masih mengabaikan keberadaan masyarakat adat yang masih mengelola tanah ulayat secara terus-menerus. Reforma hukum tanah di Indonesia belum bisa memberikan peluang hukum bagi masyarakat adat dalam memperjuangkan tanah ulayat. Terbukti tingginya konflik tanah yang juga bagian dari Sumber Daya Alam (SDA). Tingginya konflik dalam pengelolaan sumber daya alam yang terjadi

18 Hayatul Ismi, Jurnal dengan judul: Pengakuan Dan Perlindungan Hukum Hak Masyarakat Adat Atas Tanah Ulayat Dalam Upaya Pembaharuan Hukum Nasional, Jurnal di Indonesia disebabkan oleh adanya ketimpangan penguasaan Sumber Daya Alam antara masyarakat yang menggantungkan hidup dari ekonomi berbasis sumber daya alam (tanah, hutan, perkebunan, jasa lingkungan, dan lainnya) dengan penguasaan oleh sektor bisnis, khususnya sektor industri skala besar perkebunan, kehutanan dan pertambangan dan penguasaan oleh Negara yang masih menegasi adanya hak-hak masyarakat adat. ${ }^{18}$ Berkenaan dengan perlindungan hukum, tentunya dengan hukum dasar dan dasar-dasar hukum tersebut belum memberikan jaminan perlindungan hukum bagi masyarakat adat, khususnya pada obyek tanah ulayat. Menurut Fitzgerald, Teori perlindungan hukum, sebagaimana dalam Satjipto Rahardjo ${ }^{19}$, bahwa hukum bertujuan mengintegrasikan dan mengkoordinasikan berbagai kepentingan dalam masyarakat karena dalam suatu lalulintas kepentingan, perlindungan terhadap kepentingan tertentu dapat dilakukan dengan cara membagi berbagai kepentingan di lain pihak.

Pendapat ini menekankan pada pencapaian tujuan yaitu mengintegrasikan dan mengkoordinasikan berbagai kepentingan, sehingga kepentingan masing-masing dapat terlindungi dan tidak merugikan pihak lainnya. Sehingga Tanah Ulayat sebagai suatu kepentingan dari eksistensi masyarakat adat dalam mempertahankan tanah ulayatnya, maka Negara berkewajiban untuk memberikan perlindungan hukum yang sama dengan hak-hak yang lain.

\section{b. Aktualisasi Kepastian Tanah Ulayat dalam mendapatkan Statusnya dalam Hukum Indonesia}

Memang bisa dipahami bahwa keberadaan tanah ulayat sebagai bagian dari hak ulayat itu tidak ada jaminan keberlakuannya. Kenapa demikian? Karena sangat tergantung pada masyarakat

Ilmu Hukum, Vol 3, No 1, tahun 2012, tanpa halaman, download tanggal 2 Nopember 2016 19 Satjipto Raharjo, 2000, Ilmu Hukum, Bandung, Citra Aditya Bakti, hlm 53 
adat itu sendiri sebagai subyek hukum, mau mempertahankan hukum adatnya beserta hak-hak adatnya seperti tanah ulayat. Negara tidak bisa ikut campur dalam menolak kehendak masyarakat adat itu. Biasanya dalam pengamatan di beberapa tempat di Kalimantan saja. Masyarakat tanpa sadar dengan sendirinya telah mengikuti hukum formal yang dibuat Negara. Walalupun tidak sedikit daerah yang justru memperkuatnya dengan penetapan hak-hak adat dan lembaga adat. Karena bagaimana pun juga hukum yang hidup (living law) dimasyarakat, sangat tergantung pada keinginan dari masyarakatnya dalam menghendaki hukum yang berlaku di kalangan mereka. Artinya dalam bentuk apapun dalam kehidupan termasuk yang sederhana dan tradisional pun ada hukum yang mengaturnya. Sehingga ada adgium "Ubi societas ibi justicia", artinya di mana ada masyarakat dan kehidupan di sana ada hukum (keadilan). Lalu dalam ruang lingkup yang sangat besar, berupa Negara, dimana hukum diletakan sebagai penentuan pengambilan berbagai keputusan.

Aktualisasi saat ini dalam hukum di Indonesia masih dalam proses menuju bentuk, karena bentuk yang ada saat ini belum jelas terhadap status tanah ulayat. Berbagai kebijakan hukum pun dibuat, seperti Undang-undang Nomor 6 tahun 2014 tentang Desa, membagi desa menjadi 2 (dua) kelompok yaitu (1) Desa dan (2) Desa Adat. Bahkan dalam penjelasan dengan mendasarkan dalam Pasal 18B ayat (2) UUD 1945, maka dijelaskan: ${ }^{20}$ Dengan konstruksi menggabungkan fungsi selfgoverning community dengan local self government, diharapkan kesatuan masyarakat hukum adat yang selama ini merupakan bagian dari wilayah Desa, ditata sedemikian rupa menjadi Desa dan Desa Adat. Desa dan Desa Adat pada dasarnya melakukan tugas yang hampir sama. Sedangkan perbedaannya hanyalah dalam pelaksanaan hak asal-usul, terutama menyangkut pelestarian sosial Desa Adat, pengaturan dan pengurusan wilayah adat, sidang perdamaian adat, pemeliharaan ketenteraman dan ketertiban bagi masyarakat hukum adat, serta pengaturan pelaksanaan pemerintahan berdasarkan susunan asli. Hanya desa adat ini selajutnya juga masih terjadi pemutusan mata rantai dengan status tanah ulayat, karena desa adat hubungannya dengan pengaturan pemerintahan desa adat dan penyelesaian permasalahan hukum adat.

Selanjutnya dengan bentuk aktualisasi oleh Pemerintah terhadap hakhak masyarakat adat dengan mengeluarkan Peraturan Menteri Dalam Negeri RI Nomor 52 Tahun 2014 tentang Pedoman Pengakuan dan Perlindungan Masyarakat Hukum Adat. Peraturan ini sebagai petunjuk kepada Pemerintah Daerah Kabupaten, khususnya bila terdapat masyarakat adat yang menuntut untuk pengakuan hak-haknya dilakukan dengan proses, sebagai berikut:

a. Proses identifikasi Masyarakat Hukum Adat;

b. Verifikasi dan validasi Masyarakat Hukum Adat; dan

c. Penetapan Masyarakat Hukum Adat.

Tahapan ini wajib dilaksanakan, lalu siapa yang melaksanakan? tentu saja yang melaksanakan adalah Pemerintah Daerah Kabupaten, dengan susunannya adalah:

a. Sekretaris Daerah kabupaten/kota sebagai ketua;

b. Kepala SKPD yang membidangi pemberdayaan masyarakat sebagai sekretaris;

c. Kepala Bagian Hukum sekretariat kabupaten/kota sebagai anggota;

d. Camat atau sebutan lain sebagai anggota; dan

e. Kepala SKPD terkait sesuai karakteristik masyarakat hukum adat sebagai anggota.

Wilayah masyarakat adat yang akan ditetapkan sebagai wilayah adat tersebut, maka Panitia ini bekerja termasuk menerima masukan-masukan dari tokoh 
adat, kepala adat, masyarakat adat. Jadi keterlibatan mereka tidak masuk dalam kepanitiaan. Tentulah dalam hal ini bisa saja panitia tidak bisa bekerja maksimal sesuai dengan masukan yang disampaikan oleh masyarakat adat tersebut. Apalagi kekuatan Peraturan Menteri ini bisa disimpangi atau dengan kata lain tidak dilaksanakan. Mengingat Peraturan Menteri adalah peraturan teknis, bukan norma pada tingkatan undang-undang, apalagi nilai-nilai dasar dalam Konstitusi UUD 1945.

\section{PENUTUP KESIMPULAN DAN SARAN}

Dari hasil pemikiran singkat dalam makalah ini, dapat disimpulkan sebagai berikut:

1. Bahwa Hukum dan Konstitusi di Indonesia belum memberikan jaminan kepastian hukum atas obyek berupa tanah ulayat, karena sampai sekarang status tanah ulayat itu sebagai bagian tanah Negara, bukan sebagai tanah hak yang diakui secara pasti.

2. Bahwa Tanah Ulayat dalam status hukumnya belum jelas kedudukannya sebagai bagian dari tanah Negara atau sebagai tanah hak, Perintah dari Pasal 18B ayat (2) UUD 1945 untuk dibentuk Undangundang sampai saat ini belum ada undang-undang yang terkodifikasi khusus mengatur hak-hak masyarakat hukum adat yang didalamnya tentu saja termasuk Tanah Ulayat, hanya aktualisasi sekarang pun belum memberikan legitimasi yang kuat bagi kejelasan status tanah ulayat.

Oleh karenanya adapun saran yang bisa diberikan sesuai hasil analisis dan kesimpulan yang telah disampaikan, sebagai berikut:

1. Sebaiknya dalam Konstitusi UUD 1945 terkait dengan hak berupa Tanah ulayat ini bisa menjadi suatu nilai yang universial diseluruh Negara Republik Indonesia ini ada, hanya saja penerapan oleh masyarakat adat yang majemuk berbeda-beda tersebut menjadi nilai yang penting untuk memformulasikan UUD 1945 mengenai tanah ulayat.

2. Walaupun terlalu beratnya dilakukan amandemen UUD 1945, maka penting kiranya meninjau kembali UUPA sebagai Peraturan Pokok-pokok Agraria mengenai status tanah ulayat sebagai tanah hak.

\section{DAFTAR PUSTAKA}

\section{Literatur}

Bagir Manan dan Susi Dwi Harijanti, 2015, Memaknai Konstitusi, Makna dan Aktualisasi, Jakarta, Raja Grafindo Persada

Boedi Harsono, 1999, Hukum Agraria Indonesia, Sejarah Pembentukan Undang-undang Pokok Agraria, Isi dan Pelaksanaannya, Djambatan, Jakarta.

Harold J. Laski, 1947, The State in Theory and Practice, New York, The Viking Press, )

Jimly Asshiddiqie, 2000, Pembentukan dan Pembuatan Hukum, Jakarta, Universitas Indonesia

Muhammad Bakri, 2007, Hak Menguasai Tanah Oleh Negara (Paradigma Baru Untuk Reforma Agraria), Citra Media Hukum: Yogyakarta

Roestandi Ardiwilaga, 1962, Hukum Agraria Indonesia, Penerbit Masa Bakti, Jakarta

Mertokusumo, 1988, Pendaftaran Hak Atas Tanah Menurut UUPA, Karunika, Jakarta.

Satjipto Raharjo, 2000, Ilmu Hukum, Bandung, Citra Aditya Bakti.

Soedikno Mertokusumo 2002, Mengenal Hukum, Liberty, Yogyakarta

\section{Perundang-undangan}

Undang-Undang Dasar Negara Republik Indonesia Tahun 1945

Undang-undang Republik Indonesia 
Nomor 5 Tahun 1960 tentang Peraturan Dasar Pokok-pokok Agraria (Lembaran Negara Republik Indonesia Tahun 1960 Nomor 104, Tambahan Lembaran Negara Republik Indonesia Nomor 2013). Undang-Undang Nomor 6 Tahun 2014 tentang Desa (Lembaran Negara Republik Indonesia Tahun 2014 Nomor 7, Tambahan Lembaran Negara Republik Indonesia Nomor 5495);

Undang-Undang Republik Indonesia Nomor 39 Tahun 2014 Tentang Perkebunan (Lembaran Negara Republik Indonesia Tahun 2014 Nomor 308, Tambahan Lembaran Negara Republik Indonesia Nomor 5613)

Peraturan Menteri Dalam Negeri Republik Indonesia Peraturan Menteri Dalam Negeri Nomor 52 Tahun 2014 Tentang Pedoman Pengakuan Dan Perlindungan Masyarakat Hukum Adat

Peraturan Menteri Agraria dan Tata Ruang/Kepala Badan Pertanahan Nasional Nomor 9 Tahun 2015 tentang Tata Cara Penetapan Hak Komunal Atas Tanah Masyarakat Hukum Adat dan Masyarakat Yang Berada Dalam Kawasan Tertentu

\section{Sumber Lainnya}

Andi Bustamin Daeng Kunu, Kedudukan Hak Menguasai Negara Atas Tanah, Fiat Justitia Jurnal Ilmu Hukum Volume 6 No. 1 Januari-April 2012, ISSN 1978-5186, tanpa halaman, http://download.portalgaruda.org, tanggal 2 Nopember 2016

Bakrie, Abtraksi Disertasi Pembatasan

Hak Menguasai Tanah Oleh Negara Dalam Hubungannya Dengan Hak Ulayat dan Hak Perorangan Atas Tanah., Fakultas Hukum, Universitas Airlangga, http://repository.unair.ac.id/, 02 Nopember 2016

I Nyoman Nurjaya and Rachmad Syafaat, Acces to Ecological Justice For The
Marginalized People of Indonesia:

Is it a Genuine or Pseudo

Recognition and Respect, Jurnal

Indonesia Law Review, Vol 6, 1, 2016

I Nyoman Nurjaya, 2004, 2006, dalam Jurnal berjudul: Pembangunan Hukum Negara Dalam Masyarakat Multikultur: Perspektif Hukum Progresif, Jurnal Hukum Progresif, Vol 3 No.2, Oktober 2007

Hayatul Ismi, Jurnal dengan judul: Pengakuan Dan Perlindungan Hukum Hak Masyarakat Adat Atas Tanah Ulayat Dalam Upaya Pembaharuan Hukum Nasional, Jurnal Ilmu Hukum, Vol 3, No 1, tahun 2012, tanpa halaman, download tanggal 2 Nopember 2016

Yanis Maladi, Eksistensi Hukum Adat Dalam Konstitusi Negara Pasca amandemen, Jurnal Mimbar Hukum, Vol 22, Nomor 3, Oktober 2010 